\title{
Importance of Top Management Support in Its Project Success in Pakistani Context
}

\author{
Muhammad Asghar Mughal \\ mmughalasghar@gmail.com \\ School of Technology Management \& Logistic, UUM, Sintok, Kedah, Malaysia.
}

\author{
Ahmad Yusni Bahaudin.,PhD \\ aybahaudin@gmail.com \\ School of Technology Management \& Logistic, \\ UUM, Sintok, Kedah, Malaysia
}

\author{
Nurul Azita Salleh.,PhD \\ azyta@uum.edu.my \\ School of Technology Management \& Logistic, UUM, \\ Sintok, Kedah, Malaysia.
}

\begin{abstract}
Projects facing problem risks especially IT projects in Pakistan. Majority of businesses are traditionally based due to unawareness of projects procedures. This indicated that there was a lack of strategic role and it is impossible to start a temporary business norm without top management support. This was a quantitative, explorative and deductive study. The population of the study was directory member of Pakistan software board. The sample size was 223. The questionnaire was Likert scale 5 and close-ended. This study found that there was a significant and positive relationship between top management support and IT project success.
\end{abstract}

Keywords: IT projects, Pakistan, Project success, Critical success factors, Software

\section{Introduction}

Uncertainty is not a neglectable aspect of all projects especially IT project in Pakistan (Gällstedt, 2003; Tatikonda \& Rosenthal, 2000). A project manager is a strategic view with applying ingenuity, managerial, mathematics, and scientific knowledge to build solutions for technical, commercial and societal problems with strategical own decision to minimize risk due to uncertainty in an IT project. In developing and developed countries there are fashions of cutting higher project costs utilizing methods which covers valuable resources which can be used to new project development said by (Mishra, 2019). For the strategic view, the project has excellency centre is called Project Management Office (PMO). A PMO is a business unit recognised to support project managers on strategic matters (Ward, 2000). As individual project is usually one portion of larger systemic progress, the interconnection between full strategic plan and project (Engwall, 2003; Eriksson, Wikström, Hellström, \& Levitt, 2017).

The project is an intrinsic part of implementing strategies. Still, the challenge is to connect a long-term strategy to the individual projects being undertaken pointed out by (Sandhu, Al Ameri, \& Wikström, 2019). Artto and Wikström (2005) have pointed out to adverse encounters being created for the project-based organisation; one among these challenges is to meet strategic goals set for the project. More, the Enterprise Resource Planning (ERP) project was noticeably delayed and therefore enhanced costs related to problem with implementation and design (Mobekk, Fagerstrøm, \& Hantula, 2018). Due to increase uncertainty in the environment make progress in the project and leave the gap between future planning to start and what is really done. In Pakistan, Software industry requires revolutionary measures for improvement. Failure rate software projects, in Pakistan, is high. Furthermore, project management (PM) is not practiced as a full-time job in Pakistan. Practically $60 \%$ of the project related managers have not possessed formal project management training at hand. They are just managing the projects using their knowledge, experience, and personal skills (Jalil \& Hanif, 2009).

It is confirmed that project leaders track a consistent and rational approach to project management and endeavour to achieve certain organizational outcomes (Bazerman, 1994; Beach \& Connolly, 2005). In succinctly (Shore, 2008) expressed the statement as "outcome of a project can be related to the influence of cultural, leadership, project, management, and Critical Success Factors (CSFs)". More, a modern opinion of project management should accept the influence of national culture during the management of projects (Shore \& Cross, 2005; Wang \& Liu, 2007). Organizational culture advances within the setting of national culture and executive leadership (Hofstede, 1999).As executive leadership forms organizational culture, project leadership outlines project culture (Turner \& Müller, 2006)

For filling this gap, it concentrates on changes as what are targets and what is a method to reach them. This concept of changes to absorb uncertainty make it risky which is a project already facing. Today, researchers like (Choudhry \& Iqbal, 2012) admitted that project risk management (PRM) has a strong relation with Project Management keeping in view both on project success percentage and decision-making actions. Therefore, the strategic role of project manager is crucial to saving resources sometimes called top management support which has function and responsibility to get project success. 


\section{Literature Review Project Management}

An endeavour activity, as defined by the view of k Wysocki (2000), "is an arrangement of homogeneous, heterogeneous, and interlinked activities having uniform goal or purpose that must be accomplished by a definite time, within constraints of resources, and according to the description". As said by the Project Management Institute PMI (2008) and Project Management Body of Knowledge $(\mathrm{PMBoK})$ project, that is temporary endeavours conducted to accomplish desired aims and goals within the limit of unique scope, budget and time frame. The project runs thoroughly via a proper cycle of life.

The cycle of project life is sensible planning of actions to reach the goals of a project. The project life cycle (PLC) has been the source for catching and informative intrinsic fluctuations of project organizations, for an instant in sense of planning and closeout stages. However, this is only one sideways and decision phase. This is the path of watching at the behaviour of project firms. Experts like Gersick (1988) and Gersick (1989) credibly shown that PLC is not a unique clarification of how really projects progress. In this view, Kreiner (1992) said, the literature on project businesses has emphasized themes as "participation", "learning", "commitment" and "action" for the aim of focus on the behavioural aspects of such organizations.

\section{Critical Success Factors (CSFs)}

Rockart (1978) set his notions of CSFs at business and institutional level from the viewpoint of the Chief Executive but places of factors have been introduced at very many diverse levels and wide range of events and activities. Chua, Kog, and Loh (1999) and Lam, Chan, and Chan (2008) expose CSFs keeping in the view cost, time and quality. By the view of Caralli, Stevens, Willke, and Wilson (2004), the critical success factor way is a method for diagnosing chief success elements. Project success factors became a famous theme in research (Belassi \& Tukel, 1996; Pinto \& Slevin, 1988; Tishler, Dvir, Shenhar, \& Lipovetsky, 1996; White \& Fortune, 2002).

\section{Project Implementation Profile}

The PIP (Project Implementation Profile) model facilitates the project manager to measure success for a specific project via aid to weigh the occurrence of 10 identified CSFs (Pinto \& Slevin, 2006). Pinto and Slevin (1987) have a valuable contribution of PIP to project management discipline as they have a verified method to utilize CSFs to detect a project's position. They introduced sometimes called PIP tool as CSFs: client consultation, personnel, top management support, project schedule/plans, project mission, client acceptance, technical tasks, communication, monitoring and feedback, and troubleshooting (Andersen, Birchall, Arne Jessen, \& Money, 2006). Top Management Support is among strategic variables.PIP as well as IVs which is both a framework for the project implementation process as well as a diagnostic instrument for a project manager (Rosacker \& Olson, 2008).

\section{Top Management Support}

Top-management support is the greatest vital CSFs (Ang, Sum, \& Yeo, 2002). Fui-Hoon Nah, Lee-Shang Lau, and Kuang (2001), Nah, Lau, and Kuang (2001) and Jarrar, Al-Mudimigh, and Zairi (2000) highlighted that that top management is essential and distribute the required resources and time of the project in order to execute properly. Top management's support (TMS) (Arumugam, Mojtahedzadeh, \& Malarvizhi, 2011; Digalwar \& Sangwan, 2007; Umble, Haft, \& Umble, 2003) and Top management support - is surely the factor that continuously cited as the record relevant success factor in the projects of IS implementation (Hong \& Kim, 2002; Ramayah et al., 2007; Yusuf, Gunasekaran, \& Wu, 2006).

The Management support includes a facility in finance, moral, ethics and resource distribution to attain the project/business purposes in time. In the direction of the success of ERP implementation, the involvement of top management is critical (Bhatti, 2005; Kumar, Van Hillegersberg, \& Experiences, 2000 Rasmy, Tharwat, \& Ashraf, 2005). Therefore, the executive has a strategic role and Top Management Support as CSFs of PIP cover it. Schultz and Slevin (1975) stated: "management support for a project or any form of implementation has long been considered of great importance in distinguishing between their ultimate success and failure".

\section{Project Success and Project Management Success}

During a discussion at this stage, there must be made clear for two distinctions. Firstly, some authors distinguish between project management success (for measurement to cover the widespread along with traditional measurement of performance in order to cover ("cost, time and quality") and project success (measured against the overall objectives of the project). The second distinction is significant too- it shows the difference between success criteria (it is helpful via measurement to judge the business or failure or success of project) and success factors (those inputs that affect the system of management, able to lead directly or indirectly toward business or the project success (Cooke-Davies, 2002). Meanwhile, empirical works indicating the connection between CSFs (organizational factors) and their influence on project success are still insufficient (AL-DUBAI \& ALAGHBARI, 2018; Al-Sabahi, Al-Hamidi, Ramly, \& Rejab, 2014; Turner \& Müller, 2005).

\section{Project Management in Pakistani Context}

In Pakistan, Planning Commission of Pakistan is government entity and liable for the growth of projects. Planning Commission of Pakistan functions in every area of Pakistan. This body facilitates guidelines concerning to standards of quality, monitor system and planning\& control of projects (Mobey \& Parker, 2002). Pakistan is a developing country and able to make herself at a better position by taking on of human resource best practices by maximum utilization of HR resources availability which consists of more than 170 million. Among this, there are $49.19 \%$ of the female population according to the World Bank (Khanum, 2013). Since advancement entails a large number of projects and HRM is assumed as a fundamental exercise of the project-based businesses (Huemann, Keegan, \& Turner, 2007), so it is essential to estimate the impacts of practices of HR following "Universalistic Perspective" on project success of project-based organizations in Pakistan. Resource-based view (RBV) theory is underpinning for maximum utilization of all tangible and intangible resources in order to attain competitor advantage for sustainability and growth (Killen, Jugdev, Drouin, \& Petit, 2012).

\section{Methodology}

\section{Sample and Population}

This research target population is IT companies in Pakistan available on the directory of www.pseb.org.pk and they were 1720 in numbers. According to Krejcie and Morgan (1970), the sample size was 313 drawn from the population. Sampling technique was a simple random sampling. Data collection means were paperpencil and google form. 658 questionnaires distributed and usable retained $223(33.89 \%)$.

\section{Measures}

Project Implementation Profile (PIP) tool pointed out the strategic and behavioural role factor like top management support (Pinto \& Prescott, 2006). Closed-ended questionnaire adopted for selected constructs from PIP. Independent variable had five items and the dependent variable has thirteen items. Likert scale for 5 from strongly disagree (1) to strongly agree (5). Confidenve level is $95 \%$ for two tail analysis. Data analysis will perform with PLS-SEM for structure and measurement model.

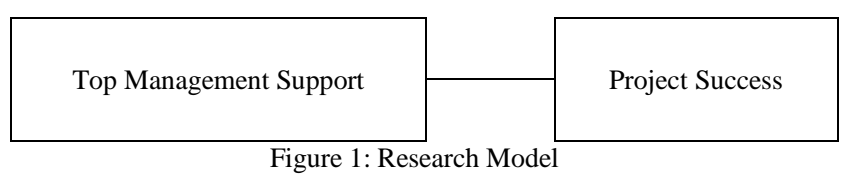

\section{Demographic Profile of the Respondents}

Majority of IT project professional were Male $87.4 \%$ with Female $12.6 \%$. Respondents holding Master were dominated with $74.4 \%$ and the minimum portion pertained to $\mathrm{PhD}$ as $0.9 \%$. There was majority of Age fall in the range of 30-39 as 56.1\% with a minimum value for the range of Above 50 as $9.9 \%$. Most professionals had an individual role for project team members--technical as 62.8 and a limited role for IT managers as $4.9 \%$. More, others consisted of e customer care, call centres and online shopping. Below is Table 1 for an explanation. 
Table 1:

Demographic Profile of Respondents

\begin{tabular}{|c|c|c|}
\hline Characteristics & Frequency & Percentage \\
\hline \multicolumn{3}{|l|}{ Gender } \\
\hline Female & 28 & 12.6 \\
\hline \multicolumn{3}{|l|}{ Education } \\
\hline Master & 166 & 74.4 \\
\hline M.Phil. & 25 & 11.2 \\
\hline Ph.D. & 2 & 0.9 \\
\hline \multicolumn{3}{|l|}{ Age } \\
\hline $20-29$ & 27 & 12.1 \\
\hline $30-39$ & 125 & 56.1 \\
\hline $40-49$ & 49 & 22.0 \\
\hline Above 50 & 22 & 9.9 \\
\hline \multicolumn{3}{|c|}{ Work Experience in IT Industry } \\
\hline 1-5 Years & 148 & 66.4 \\
\hline 6-10 Years & 34 & 15.2 \\
\hline Above 11 Years & 24 & 10.8 \\
\hline \multicolumn{3}{|l|}{ Your Individual Role } \\
\hline Project Manager & 11 & 4.9 \\
\hline $\begin{array}{l}\text { The manager on Project } \\
\text { team }\end{array}$ & 17 & 7.6 \\
\hline $\begin{array}{l}\text { Project team member } \\
\text { (Technical) }\end{array}$ & 140 & 62.8 \\
\hline $\begin{array}{l}\text { Project team member } \\
\text { (Administrative) }\end{array}$ & 37 & 16.6 \\
\hline Others & 18 & 8.1 \\
\hline
\end{tabular}

This is quantitative, deductive and explorative study. Here are hypotheses for study

H1. There is a significate relationship Top Management Support and Project Success.

IThis study has one CSF related to a strategic role like top management support to measure project success. This is quantitative and explorative study in IT projects in Pakistan. Unit of analysis was individual. This is shown in Figure 1.

\section{Analysis and Results}

At the initial stage of analysis, the assumptions pertain to linearity, multicollinearity and normality were measured (Hair, Ringle, \& Sarstedt, 2011; Tabachnick \& Fidell, 2001). After fulfilling the required assumptions, the (PLS) partial least square path modelling (Wold, 1974, 1985) using Smart PLS 3.0 (Ringle, Wende, \& Will, 2005).

\section{Measurement Model Outcomes}

Each item reliability, reliability for internal consistency and discriminant validity were confirmed for measuring the psychometric possessions of the scales that have been exercised in the current study. For the sake of determining each item reliability, the outer loadings were utilized similar to (Hair Jr, Hult, Ringle, \& Sarstedt, 2016)

\section{Table 2:}

Results of Measurement Model

$\begin{array}{llcccc}\begin{array}{l}\text { Construct } \\ \text { Top }\end{array} & \text { Items } & \text { Loading } & \begin{array}{c}\text { Cronbach } \\ \text { 's Alpha }\end{array} & \text { AVE } & \text { CR } \\ \begin{array}{l}\text { Managemen } \\ \text { t Support }\end{array} & \text { TMS1 } & 0.858 & 0.901 & 0.770 & 0.930 \\ & \text { TMS2 } & 0.885 & & & \\ & \text { TMS3 } & 0.895 & & & \\ & \text { TMS4 } & 0.871 & & & \\ \text { Project } & \text { PS1 } & 0.704 & 0.912 & 0.531 & 0.926 \\ \text { Success } & & & & & \end{array}$

PS2 0.702

PS3 0.748

PS4 0.777

PS5 $\quad 0.746$

PS6 $\quad 0.658$

PS7 $\quad 0.772$

PS8 $\quad 0.732$

PS10 0.726

PS12 0.711

PS13 0.736

The items which contained 0.5 and higher loadings were retained (Barclay, Higgins, \& Thompson, 1995; Chin, 1998). Table 2 presented loadings. More, in order to determine internal consistency reliability, the composite reliability coefficient was utilized which followed to (Bagozzi \& Yi, 1988) and (Hair et al., 2011) may be minimum 0.7 or above (refer table 2 ). Therefore, it can be supposed that the current study qualifies the internal consistency reliability.

The average variance extracted (AVE) was assumed for defining discriminant validity depicted on the recommendations of (Fornell \& Bookstein, 1982). According to whom the square root of AVE may be greater than the correlations among latent variables. The results of discriminant validity are presented in Table 3

Table 3:

Discriminate Validity

\begin{tabular}{ccc}
\hline & PS & TMS \\
\hline PS & $\mathbf{0 . 7 2 9}$ & \\
TMS & 0.444 & $\mathbf{0 . 8 7 7}$ \\
\hline
\end{tabular}

Note: Bold diagonal figures are the square root of AVE.

\section{Structure and Model Results}

To measure the significance of the path coefficients the bootstrapping method was run for 223 cases with 5000 bootstraps (Hair, Sarstedt, Ringle, \& Mena, 2012). The path coefficients are shown in Table 4 and Figure 2.

Table 4:

Path Coefficients and Hypothesis testing

\begin{tabular}{lllllll}
\hline & & \multicolumn{3}{c}{ T } & P & \\
& & Beta & SE & Statistics & Values & Decision \\
\hline \multirow{2}{*}{ H1 } & TMS -> & 0.44 & 0.0 & \multirow{2}{*}{$7.478^{* * *}$} & \multirow{2}{*}{0.000} & \multirow{2}{*}{ Supported } \\
& PS & 4 & 59 & & & \\
\hline
\end{tabular}

Note. Two-tailed test. Significant at $\mathrm{p}<0.05^{*}, \mathrm{p}<0.01^{* *}$ and $\mathrm{p}<0.001 * * *$

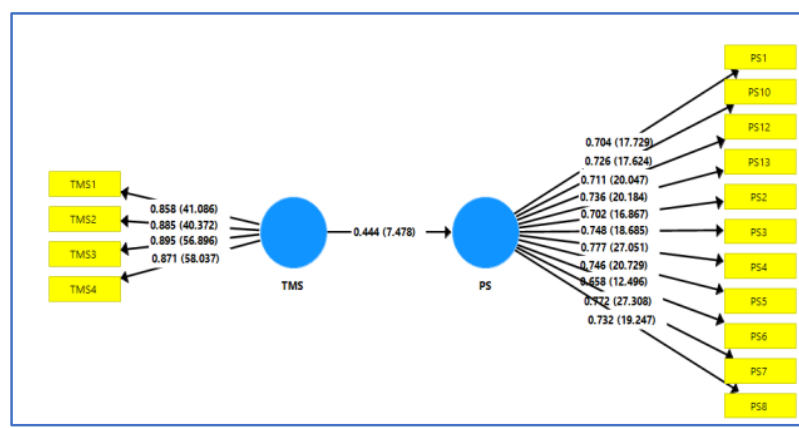

Figure 2: Assessment of the structural model

The association between top management support and project success is postulated in Table 4. According to this, the path coefficient from top management support to project success is 0.444 (t-value $=7.47$ ). It is regarded that there is a relationship between top management support and project success. Table 5 presents the $\mathrm{R}^{2}$ value of project success which is 0.19 . This notifies us that the top management support explains 19 per cent of the variance in the project success. All the above value fulfils the assumptions.

\begin{tabular}{lr} 
Table 5: Variance Explained in the Endogenous Variable \\
\hline Latent Variable & R-square \\
\hline Project Success & $19 \%$ \\
\hline
\end{tabular}




\section{Conclusion and Recommendations}

The purpose of this paper was to create awareness about project management and assess the relationship between top management support and project success. Results revealed that behavioural and strategic factor top management support has a positive and significant relationship with project success. This is confirmed by Rosacker and Olson (2008) as "The information, as well as insights on Top Management Support, has positive impact presented by this study can be of assistance in attaining successful project". These findings are also consistent with (Belout \& Gauvreau, 2004; Pinto \& Prescott, 1988; Rosacker \& Olson, 2008; Rosacker, Zuckweiler, \& Buelow, 2010).

This study discourses the investigation of top management support with project success among the project managers of exportoriented of IT companies in Pakistan. Drawing upon RBV theory the findings suggest a positive linkage between the two. Hence it is suggested to broaden the scope of this study into the other local business IT companies of the country to well explicate this association and collect further valuable data to validate these outcomes.

Besides, only top management support was examined under current study. Therefore, it is also recommended to inspect the influence of accountability over project success in the IT industry. Current research might also have limitations certainly due to its crosssectional design. Further analysis on a longitudinal basis is suggested. Although the current research has many limitations despite that it informs a positive relationship between top management support and project success between. Thus, it can be concluded that the strategic role of top management support has a great impact on project success.

\section{References}

i. AL-DUBAI, M. M., \& ALAGHBARI, M. A. (2018). RELATIONSHIP BETWEEN ORGANIZATIONAL FACTORS TOWARD PROJECT SUCCESS. Journal of Internet Banking and Commerce, 23(2).

ii. Al-Sabahi, M. H., Al-Hamidi, A. A., Ramly, A., \& Rejab, K. M. (2014). Exploring criteria and critical factors for governmental projects implementation in Yemen: a case study. Journal of Surveying, Construction and Property, 5(2), 1-17.

iii. Andersen, E. S., Birchall, D., Arne Jessen, S., \& Money, A. H. (2006). Exploring project success. Baltic journal of management, 1(2), 127-147.

iv. Ang, J. S., Sum, C.-C., \& Yeo, L.-N. (2002). A multiple-case design methodology for studying MRP success and CSFs. Information \& Management, 39(4), 271-281.

v. Artto, K. A., \& Wikström, K. (2005). What is project business? International journal of project management, 23(5), 343-353.

vi. Arumugam, V., Mojtahedzadeh, R., \& Malarvizhi, C. (2011). Critical success factors of total quality management and their impact on performance of Iranian Automotive Industry. Paper presented at the International Conference on Innovation, Management and Service IPEDR.

vii. Bagozzi, R. P., \& Yi, Y. (1988). On the evaluation of structura equation models. Journal of the Academy of Marketing Science, 16(1), 74-94.

viii. Barclay, D., Higgins, C., \& Thompson, R. (1995). The partial least squares (PLS) approach to casual modeling: personal computer adoption ans use as an Illustration.

ix. Bazerman, M. (1994). Judgment in managerial decision making. New York: Wiley.

x. Beach, L. R., \& Connolly, T. (2005). The psychology of decision making: People in organizations: Sage.

xi. Belassi, W., \& Tukel, O. I. (1996). A new framework for determining critical success/failure factors in projects International journal of project management, 14(3), 141-151.

xii. Belout, A., \& Gauvreau, C. (2004). Factors influencing project success: the impact of human resource management. International journal of project management, 22(1), 1-11.

xiii. Bhatti, R. (2005). Critical success factors for the implementation of ERP: Empirical validation. Paper presented at the The second International Conference on Innovation in Information Technology (ITT'05) in Dubai, UAE (Sept 26-28, 2005). xiv. Caralli, R. A., Stevens, J. F., Willke, B. J., \& Wilson, W. R. (2004). The critical success factor method: establishing a foundation for enterprise security management. Retrieved from

xv. Chin, W. W. (1998). The partial least squares approach to structural equation modeling. In: Marcoulides, G.A. (Ed.), Modern Methods for Business Research. Erlbaum, Mahwah, 295-358.

xvi. Choudhry, R. M., \& Iqbal, K. (2012). Identification of risk management system in construction industry in Pakistan. Journal of management in engineering, 29(1), 42-49.

xvii. Chua, D. K. H., Kog, Y.-C., \& Loh, P. K. (1999). Critical success factors for different project objectives. Journal of construction engineering and management, 125(3), 142-150.

xviii. Cooke-Davies, T. (2002). The "real" success factors on projects. International journal of project management, 20(3), 185-190.

xix. Digalwar, A. K., \& Sangwan, K. S. (2007). Development and validation of performance measures for world class manufacturing practices in India. Journal of Advanced Manufacturing Systems, 6(01), 21-38.

xx. Engwall, M. (2003). No project is an island: linking projects to history and context. Research policy, 32(5), 789-808.

xxi. Eriksson, K., Wikström, K., Hellström, M., \& Levitt, R. (2017). Governance of business ecosystem projects, working paper series, Proceedings of the EPOC-MW Conference, Engineering Project Organization Society, Fallen Leaf Lake, CA, 5-8 June.

xxii. Fornell, C., \& Bookstein, F. L. (1982). Two structural equation models: LISREL and PLS applied to consumer exit-voice theory. Journal of marketing research, 19(4), 440-452.

xxiii. Fui-Hoon Nah, F., Lee-Shang Lau, J., \& Kuang, J. (2001). Critical factors for successful implementation of enterprise systems. Business Process Management Journal, 7(3), 285-296.

xxiv. Gällstedt, M. (2003). Working conditions in projects: perceptions of stress and motivation among project team members and project managers. International journal of project management, 21(6), 449-455.

xxv. Gersick, C. J. (1988). Time and transition in work teams: Toward a new model of group development. Academy of management journal, 31(1), 9-41.

xxvi. Gersick, C. J. (1989). Marking time: Predictable transitions in task groups. Academy of management journal, 32(2), 274-309.

xxvii. Hair, J. F., Ringle, C. M., \& Sarstedt, M. (2011). PLS-SEM: Indeed a silver bullet. Journal of Marketing theory and Practice, 19(2), 139-152.

xxviii. Hair, J. F., Sarstedt, M., Ringle, C. M., \& Mena, J. A. (2012). An assessment of the use of partial least squares structural equation modeling in marketing research. Journal of the Academy of Marketing Science, 40(3), 414-433.

xxix. Hair Jr, J. F., Hult, G. T. M., Ringle, C., \& Sarstedt, M. (2016). A primer on partial least squares structural equation modeling (PLS-SEM): Sage publications.

xxx. Hofstede, G. (1999). Problems remain, but theories will change: the universal and the specific in 21 st century global management. Organizational dynamics, 27(1), 34-34.

xxxi. Hong, K.-K., \& Kim, Y.-G. (2002). The critical success factors for ERP implementation: an organizational fit perspective. Information \& Management, 40(1), 25-40.

xxxii. Huemann, M., Keegan, A., \& Turner, J. R. (2007). Human resource management in the project-oriented company: A review. International journal of project management, 25(3), 315-323.

xxxiii. Jalil, Z., \& Hanif, A. (2009). Improving management of outsourced software projects in Pakistan. Paper presented at the Computer Science and Information Technology, 2009. ICCSIT 2009. 2nd IEEE International Conference on.

xxxiv. Jarrar, Y. F., Al-Mudimigh, A., \& Zairi, M. (2000). ERP implementation critical success factors-the role and impact of business process management. Paper presented at the Management of Innovation and Technology, 2000. ICMIT 2000. Proceedings of the 2000 IEEE International Conference on

xxxv. k Wysocki, R. (2000). Robe Beck Jr, David B Crane. Effective Project Management.

xxxvi. Khanum, A. (2013). An Overview of Pakistani Women in Education, Science and Research. 
xxxvii. Killen, C. P., Jugdev, K., Drouin, N., \& Petit, Y. (2012) Advancing project and portfolio management research: Applying strategic management theories. International journal of project management, 30(5), 525-538.

xxxviii. Kreiner, K. (1992). The Postmodem Epoch of Organization Theory. International Studies of Management \& Organization, 22(2), 37-52.

xxxix. Krejcie, R. V., \& Morgan, D. W. (1970). Determining sample size for research activities. Educational and psychological measurement, 30(3), 607-610.

xl. Kumar, K., Van Hillegersberg, J., \& Experiences, E. (2000). Evolution. Communications of the ACM, 43(4), 23-26.

xli. Lam, E. W., Chan, A. P., \& Chan, D. W. (2008). Determinants of successful design-build projects. Journal of construction engineering and management, 134(5), 333-341.

xlii. Mishra, A. K. (2019). Implementation Status of Value Management in Project Management Practice in Nepal. International Journal of Management Studies, 6(1), 1.

xliii. Mobekk, H., Fagerstrøm, A., \& Hantula, D. A. (2018). The Influence of Probability Discounting on Escalation in Information Technology Projects. International Journal of Information Technology Project Management (IJITPM), 9(1), 23-39.

xliv. Mobey, A., \& Parker, D. (2002). Risk evaluation and its importance to project implementation. Work Study, 51(4), 202208

xlv. Nah, F. F.-H., Lau, J. L.-S., \& Kuang, J. (2001). Critical factors for successful implementation of enterprise systems. Business Process Management Journal, 7(3), 285-296.

xlvi. Pinto, J. K., \& Prescott, J. E. (1988). Variations in critical success factors over the stages in the project life cycle. Journal of management, 14(1), 5-18

xlvii. Pinto, J. K., \& Prescott, J. E. (2006). Changes In Critical Success Factor Importance Over the Life of a Project.

xlviii. Pinto, J. K., \& Slevin, D. P. (1987). Critical factors in successful project implementation. IEEE transactions on engineering management (1), 22-27.

xlix. Pinto, J. K., \& Slevin, D. P. (1988). Project success: definitions and measurement techniques.

1. Pinto, J. K., \& Slevin, D. P. (2006). Critical factors in successful project implementation.IEEE transactions on engineering management (1), 22-27.

li. Ramayah, T., Roy, M. H., Li, K. B., Jantan, M., Zbib, I., \& Ahmed, Z. (2007). Type of procurement and operational performance: comparing e-procurement and offline purchasing. International Journal of Services and Operations Management 3(3), 279-296

lii. Rasmy, M., Tharwat, A., \& Ashraf, S. (2005). Enterprise resource planning (ERP) implementation in the Egyptian organizational context. Paper presented at the Proceedings of the EMCIS International Conference.

liii. Ringle, C. M., Wende, S., \& Will, S. (2005). SmartPLS 2.0 (M3) Beta, Hamburg 2005. In

liv. Rockart, J. F. (1978). Chief executives define their own data needs. Harvard business review, 57(2), 81-93.

1v. Rosacker, K. M., \& Olson, D. L. (2008). Public sector information system critical success factors. Transforming Government: People, Process and Policy, 2(1), 60-70.

lvi. Rosacker, K. M., Zuckweiler, K. M., \& Buelow, J. R. (2010). An empirical evaluation of hospital project implementation success. Academy of Health Care Management Journal, 6(1), 37.

1vii. Sandhu, M. A., Al Ameri, T. Z., \& Wikström, K. (2019) Benchmarking the strategic roles of the project management office (PMO) when developing business ecosystems Benchmarking: an international journal.

1viii. Schultz, R. L., \& Slevin, D. P. (1975). Implementing operations research: American Elsevier.

lix. Shore, B. (2008). Systematic biases and culture in project failures. Project management journal, 39(4), 5-16.

1x. Shore, B., \& Cross, B. J. (2005). Exploring the role of national culture in the management of large-scale international science projects. International journal of project management, 23(1), $55-64$. 1xi. Tabachnick, B. G., \& Fidell, L. S. (2001). Using multivariate statistics (Vol. 5). Nedham Heights, MA: Allyn \& Bacon.

1xii. Tatikonda, M. V., \& Rosenthal, S. R. (2000). Successful execution of product development projects: Balancing firmness and flexibility in the innovation process. Journal of Operations Management, 18(4), 401-425.

1xiii. Tishler, A., Dvir, D., Shenhar, A., \& Lipovetsky, S. (1996). Identifying critical success factors in defense development projects: A multivariate analysis. Technological forecasting and social change, 51(2), 151-171.

lxiv. Turner, J. R., \& Müller, R. (2005). The project manager's leadership style as a success factor on projects: A literature review.

lxv. Turner, J. R., \& Müller, R. (2006). Choosing appropriate project managers: Matching their leadership style to the type of project.

1xvi. Umble, E. J., Haft, R. R., \& Umble, M. M. (2003). Enterprise resource planning: Implementation procedures and critical success factors. European journal of operational research, 146(2), 241-257.

lxvii. Wang, X., \& Liu, L. (2007). Cultural barriers to the use of Western project management in Chinese enterprises: Some empirical evidence from Yunnan province. Project management journal, 38(3), 61-73.

lxviii. Ward, J. L. (2000). Project management terms: a working glossary: ESI Intl.

1xix. White, D., \& Fortune, J. (2002). Current practice in project management-An empirical study. International journal of project management, 20(1), 1-11.

1xx. Yusuf, Y., Gunasekaran, A., \& Wu, C. (2006). Implementation of enterprise resource planning in China. Technovation, 26(12), 1324-1336. 